вираження. При виявленні словотвірного значення важливими $\epsilon$ частиномовна характеристика композита, семантика складових компонентів, структурна характеристика та змістові відношення між ініціальним та фінальним компонентами.

\title{
Література:
}

1. Алефіренко Н.Ф. Спорные проблемы семантики : монография. Москва : Гнозис, 2005. 326 с.

2. Земская Е.А. Словообразование как деятельность. Москва : Изд-во ЛКИ, 2007. 224 с.

3. Іщенко Н.Г. Словотвірне значення та форма його реалізації. Вісник Київського національного лінгвістичного університету. Серія Філологія. Київ, 2002. Т. 4. С. 127-137.

4. Коломойцев В.Э. Универсальный словарь экономических терминов: инвестирование, конкуренция, менеджмент, маркетинг, предпринимательство : учеб. пособие. Київ : Молодь, 2002. 416 с.

5. Кубрякова Е.С. Типы языковых значений: Семантика производного слова. Москва : Наука, 1981. 200 с.

6. Лопатин В.В. Русская словообразовательная морфемика. Москва : Наука, 1977. 315 с.

7. Плющ М. Я., Бевзенко С.П., Грипас Н.Я. Сучасна українська літературна мова: підручник. Київ : Вища школа, 2004. 430 с.

DOI https://doi.org/10.30525/978-9934-588-90-7-34

\section{МОРФОЛОГІЧНІ ОСОБЛИВОСТІ АНГЛОМОВНИХ РЕКЛАМНИХ СЛОГАНІВ}

\author{
Грищук Д. А. \\ студентка кафедри германської філології \\ Сумський державний університет \\ м. Суми, Украӥна
}

Реклама як один із найважливіших різновидів масової комунікації міцно увійшла в життя сучасної людини. Реклама, нині - невід'ємна частина людського побуту, за останні десятиліття набула унікальних особливостей та характеристик. Останнім часом рекламний слоган привертає до себе особливу увагу лінгвістів (А. Годдард, Р. Голдман, Дж. Ліч, а також Т. А. Безугла, I. В. Городецька, М. М. Кохтєв, 
C. В. Нікітіна та ін.) як результат поєднання різнорівневих мовних засобів задля реалізації певної прагматики. Наукові диспути стосовно мовної специфіки рекламних слоганів подекуди лише підвищують інтерес науковців до цієї теми, що визначає актуальність поданого дослідження.

Е. В. Ромат визначає рекламний слоган як вагомий складник структури рекламного тексту, який у поєднанні $з$ логотипом, передає основний сенс рекламної концепції та несе вербальне навантаження реклами. Учена також називає рекламний слоган самостійним жанровим видом рекламного тексту [3, с. 14]. Дослідники виділяють такі характеристики слогана як стислість, самостійність та змістовність [2, с. 39]; незалежність, орієнтованість на споживача, маніпулятивність [1, с. 121]; емотивність [4, c. 142].

Аналіз емпіричного матеріалу морфологічного аспекту слоганів продемонстрував значні відмінності, а саме: фреквентативність вживання субстантивів; акційних лексем; ад'єктивів та адвербів позитивно-оцінної семантики; використання прономінальних лексем.

Субстантиви домінують серед морфологічних виражальних засобів завдяки вдалій актуалізації інформаційної та прагматичної функцій рекламного тексту. Зокрема, рекламні слогани використовують іменники для позначення кількох основних категорій:

1) тип рекламованого товару (cava (champagne), coat, concealer, jewelry, oil, perfume, fragrance): Meet America's \#1 concealer (Maybelline);

2) об'єкт, для яких пропонований продукт виготовлений (body, hair, skin, legs, look, eyes, life): Wake up to youthful, hydrated skin (Aveeno);

$3)$ результат, який реципієнт отримає після користування товаром (difference, holiday, perfection, taste, bliss, beauty, love, possibilities); Holiday like never before ( $P \& O$ Cruises); ад

4) характеристика товару, за допомогою якої результати досягаються (art, innovation, nature, science, therapy): The artisan of emotions (Chopard).

Емпіричний матеріал показав, що ужиті субстантиви реалізують апелятивну функцію - привертають увагу до товару, не називаючи його: Turkish Reflection (Turkish Airlines). Відзначимо, що окрім апелятивів, до тестів слогану залучають і субстантивна позначення результату від використання товару: краса (beauty), здоров'я (health), сила (strength), перспективи (future/perspectives) та ін.: Your hair and its beauty at any age (Viviscal).

Ад'єктиви посідають друге місце за частотою використання за рахунок їх здатності актуалізувати цільові емоції у споживачів. Так, Дж. Ліч у своїй розвідці навів досить повний перелік [5] найуживаніших прикметників: 1. new (Make room for our new balloon jeans (Levi's)); 2. good/best (Feel good inside (Sainsbury's Home)); 3. free; 4. fresh; 128 
5. delicious; 6. full; 7. sure; 8. Clean (Clean formulas, no filters (Timeless skincare)); 9. wonderful; 10. special; 11. crisp; 12. fine; 13. big; 14. Great (Great hair though (Aussie)); 15. real; 16. Easy (Smoothing out wrinkles? Easy. Give it a week (Neutrogena)); 17. bright (Bright new you (Postscript clothes)); 18. extra; 19. safe; 20. rich.

Відзначимо також часте вживання вищої та найвищої форм ступенів порівняння прикметників типу better, the best та ін.: Bigger. Better. Grande (Grande Cosmetics); More blonde. Less brass (Moroccanoil); Avaxhome - the biggest Internet portal (Avaxhome).

Лексеми на позначення акційності здебільшого відповідають за створення динамічності тексту: актуалізуючи процес перетворення у когніції реципієнта, дієслова наштовхують його на дії, пов'язані 3 уживанням продукту. Варто зазначити, що в слоганах дієслова вжиті переважно в теперішньому неозначеному часі або у формі наказового способу: Erase. Correct. Shape (Maybelline); Discover the Spanish taste for life (Segura Viudas); Turn back the clock (Merle Norman Cosmetics); Collect moments (Effy Jewelry); Sign your lips (L'Oreal Paris).

Прономінальні лексеми покликані персоніфікувати рекламу, допомагаючи сформувати діалог між рекламодавцем та цільовою аудиторією через рекламний слоган, до прикладу: TRES smoothed. TRES defined. TRES you (TRESemme); Your stories through scent (National Fragrance Week); Innovation and you (Phillips); Bend your reality (AOC Gaming); Together, we'll get through this (Fort Myers and Sanibel Resort); My Lagos. My way (Lagos Jewelry).

Емпіричний матеріал продемонстрував, що використання адвербіальних одиниць хоча $\epsilon$ порівняно нечастим, але досить ефективним. Так, у випадках їх уживання, наприклад: Explore year-round (Recharge Tours); Celebrate tomorrow by choosing today (Paper \& Packaging); Vuse charge beyond (Vuse Vapor), їх основною функцією $\epsilon$ уточнення ознаки або дії продукту.

Проаналізованим частинам мови у рекламних слоганах характерний особливий психологічно-прагматичний вплив на читачів реклами. Найуживанішими виявилися іменники, прикметники та дієслова. Прислівники використовувались для уточнення та підсилення оцінних характеристик. Окремо слід відзначити роль займенників, оскільки вони персоніфікують текст слогану, наближуючи аудиторію до продукту.

\section{Література:}

1. Вінарєва О. В. Структурний, семантичний і прагматичний аспекти англомовних торгових назв (на матеріалі веб-сайтів мережі Інтернет): дис. ... канд. філол. наук: 10.02.04. Київ, 2005. 327 с.

2. Романова Т. Н. Слоганы в языке современной рекламы. Лингвистика. 2001. № 3. С. 32-38. 
3. Ромат Е. В. Реклама. Харьков: Студцентр, 2000. 480 с.

4. Черешнева Ю. Е. Промоушн печатных СМИ. Москва: Рипхолдинг, 2006. 262 с.

5. Leech G. N. English in Advertising: A Linguistic Study of Advertising in Great Britain. London: Longman, 1966. 210 p.

DOI https://doi.org/10.30525/978-9934-588-90-7-35

\title{
КОМУНІКАТИВНА СТРУКТУРА ВИСЛОВЛЮВАННЯ ТА ЗАСОБИ П̈Ї ВИРАЖЕННЯ В АНГЛІЙСЬКІЙ МОВІ
}

\author{
Гусейнова К. С. \\ викладач кафедри іноземних мов № 1 \\ Національний університет «Одеська юридична академія» \\ Бубнов Д. В. \\ викладач кафедри іноземних мов № 1 \\ Начіональний університет «Одеська юридична академія» \\ м. Одеса, Україна
}

Проблема аналізу засобів комунікативної організації висловлювання, незважаючи на відносну вивченість, залишається актуальною та продовжує привертати увагу дослідників.

Добре відомо, що в мовах світу існують кілька способів маркування компонентів комунікативної структури. Основними і універсальними 3 них прийнято вважати порядок слів та інтонацію. Комунікативна структура висловлювання найчастіше знаходить реалізацію саме у взаємодії фразової просодії та порядку слів, які утворюють в термінології Т. Є. Янко «линейно-акцентную структуру» [1].

Зіставлення ролі порядку слів та його взаємодії 3 інтонаційними засобами у визначенні комунікативного навантаження слова на матеріалі англійської мови становить інтерес тому, що англійська є мовою 3 жорстким або твердим порядком слів.

Основною функцією порядку слів в англійській мові $є$ граматична, вона висловлює певні синтаксичні відносини, а «вираз лексичного підмета та лексичного присудка $\epsilon$ менш важливим, ніж вираз граматичних відносин між словами» [2, с. 69]. Зазвичай в розповідному англійському реченні підмет - тема передує присудок - рема.

Оскільки базовим порядком слів в англійській мові є SVO (де S підмет, суб'єкт, V - дієслово - присудок, $\mathrm{O}$ - додаток, об'єкт), в незалеж130 